BOOKS

\title{
Progress and pain on the path of humanitarian medicine
}

Previously published at www.cmaj.ca

Globalization and Health: Pathways,

Evidence and Policy

Ronald Labonté, Ted Schrecker, Corinne

Packer and Vivian Runnels, editors.

Routledge; 2009.

\section{Concepts and Practice of Humanitarian Medicine}

S. William A. Gunn and Michele Masellis, editors.

Springer; 2008.

I $\mathrm{n}$ light of the faltering progress in achieving health related targets during the current global economic downturn, these are timely books, reminding us of the importance and practice of humanitarian medicine.

In Concepts and Practice of Humanitarian Medicine, 31 prestigious contributors share historical perspectives on human rights, poverty reduction and health, primarily through the focused lens of the International Association of Humanitarian Medicine Brock Chisholm and the work of the World Health Organization (WHO). There are omissions (for example, Médecins Sans Frontières is dismissed in the preface), but important, thought-provoking points are made.

Humanitarian medicine is described as rights-based and political. Examples are given of pioneers who have confronted inequities in health, taking risks to support marginalized groups such as torture victims, tribal minorities and delivering women. The book also illustrates that humanitarian medicine is inclusive. Whether you are a cardiac surgeon or repair cleft palates in chil$\&$ dren, there is a way to focus your work to help the less fortunate. Encouragement is given in the book to fight harder and better to achieve humanitarian goals and not let anger and battle fatigue make aid providers crazy - sometimes literally. The authors describe Dr. Ignaz

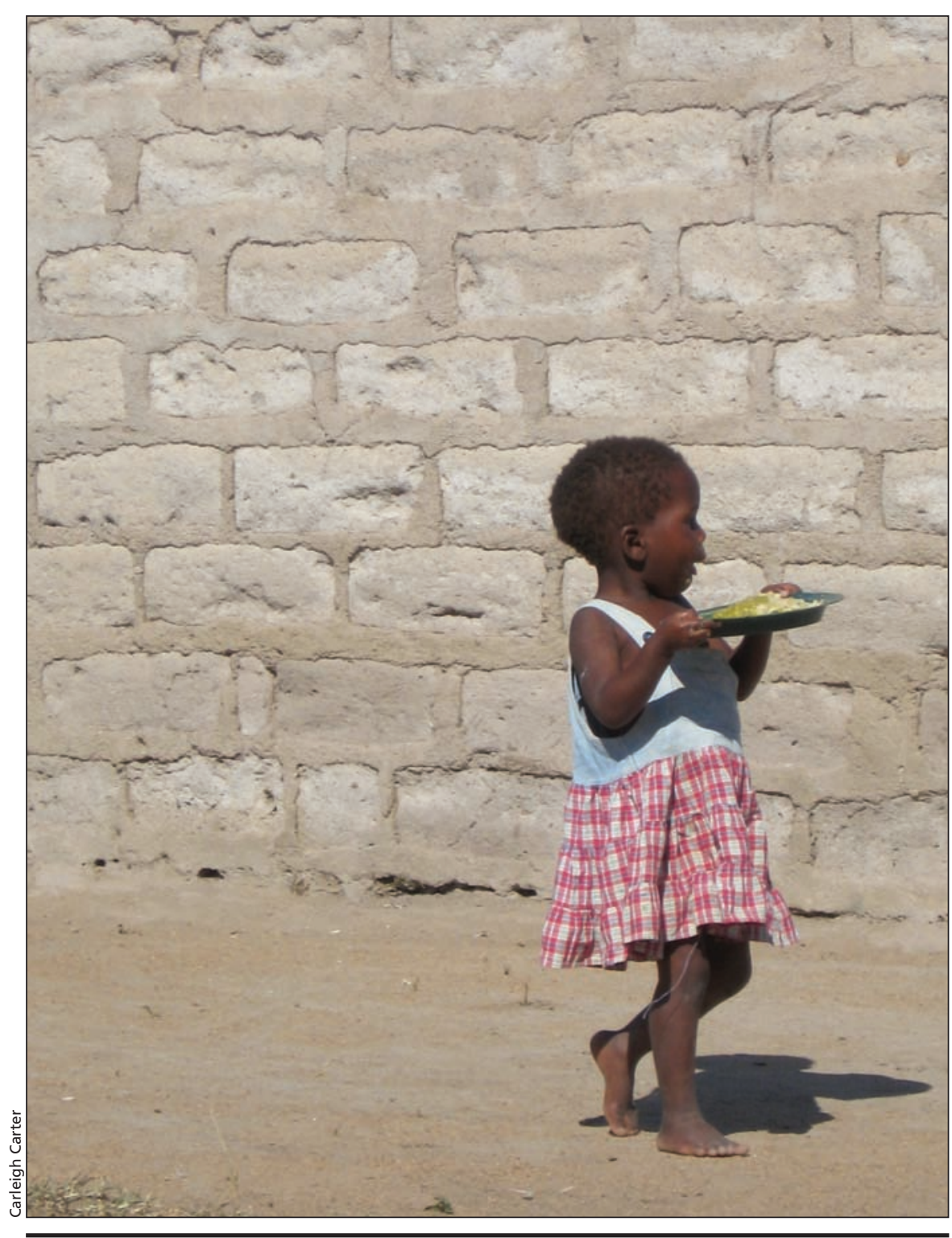

This photograph is unrelated to these books, but was among the top three entries in a contest at the McMaster International Women's and Children's Health Network conference in 2009. The child, who is HIV-positive, carries the one hot meal she received daily. It was given to her at the community Neighbourhood Care Point in Nkambeni, Swaziland. "Use of Both Hands" was taken by Hamilton, Ont., nursing student Carleigh Carter.

Semmelweis who died at age 47 in a mental hospital, worn out from trying to convince his obstetrical colleagues that they were contributing to the deaths of their patients from puerperal sepsis.
In this book, Halfdan Mahler reminds us that "Visionaries have always been the realists of humankind's history." Mahler envisioned the WHO Primary Health Care strategy initiated 30 years 
ago at Alma Ata, which is the underpinning of the Millennium Development Goals. He reflects the words of the founder of social medicine, Rudolf Virchow at age 30, also quoted in the book:

"If they do not create the current, they still give it its direction and force. These [people] are not always the happiest. Many go down in the movement, or by it. Many grow weary, after they have given it their best forces. Much power and great tenacity are necessary, if the individual shall not only live to see its triumph but also to enjoy it."

Whet your appetite with Humanitarian Medicine, then read Globalization and Health. In this well-documented and tightly edited book, a strong interdisciplinary collection of 24 authors logically present arguments derived from the Globalization Knowledge Network of the WHO Commission on Social Determinants of Health. Funded by the International Affairs Directorate of Health Canada with support from the Institute of Population Health at the University of Ottawa, the authors follow well in the tradition of Brock Chisholm, the Canadian physician who was the first director-general of WHO.

Many may find this second volume more controversial. It clearly articulates a complex analysis of factors in globalization and health that have constrained health outcomes, such as the 10 million children under five years old who still die every year - $97 \%$ of them in the developing world - and the reduction of maternal deaths, which has made little progress especially in sub-Saharan Africa. The limited role of medicine in a tough macroeconomic environment is well explained and the economic theory presented, as well as the political analysis, is focused and rooted in the field realities. The effectiveness of aid in reducing poverty and improving health outcomes is well analyzed. The book explains that less than one-quarter of official development assistance is targeted to the poorest countries and 60\% of the total increase in this assistance between 2001 and 2004 went to Afghanistan, the Democratic Republic of Congo and Iraq, which are home to only $3 \%$ of the developing world's poor, but are, indisputably, of geopolitical importance.

There has been intense international debate on some of the premises of this book. The World Bank and the International Monetary Fund have already countered $^{1}$ Ted Schrecker and Gorik Ooms' challenging 2005 article, ${ }^{2}$ criticizing the arguments about the negative impacts of these multilateral agencies. This book will add more fuel to the debate.

Read it yourself and decide whether you are convinced that the marketbased principles of the G7 and three multilateral agencies - the World Bank, International Monetary Fund and World Trade Organization - have had unintended effects which have undermined equitable access to health care and the social determinants of health, in spite of poverty reduction strategies. The negative impacts of structural adjustment (e.g., reduced social sector spending, user fees for health care, removal of subsidies on basic foodstuffs and civil service freezes contributing to the brain drain from poor rural areas in developing countries to wealthier ones) are cited as "reforms" which have contributed to income inequality, a major determinant of health outcomes. The mixed results of the Heavily Indebted Poor Countries initiative, the changing aid architecture (e.g., the Paris Declaration, the move to sector-wide approaches (SWAps) and budget support, and the contribution of the Global
Health initiatives toward distorting fiscal space and health system development) are logically explained.

HIV/AIDS is one area where, in spite of the socio-economic drivers of the disease, efforts have been stronger to fund treatment. The book explains how this medical model has consumed funding that has marginalized other priorities because of countries' own efforts to limit sectoral spending in health. The book explains how this paradigm has also diverted attention away from prevention, has helped to further skew resource allocation to urban areas and has strained already weak health systems with an internal brain drain.

These are important books for introducing young physicians and intersectoral health activists to the evolution of humanitarian medicine, the architecture of aid, the status of the Millennium Development Goals and the social determinants of health. If you feel a call to action, these can help prepare you. Or if you want to gain a deeper understanding of the challenges and politics of health development, these are helpful guides. The first book gives the theory, through the normative standard-setting role of the UN agencies. The second book is more analytical, interwoven and practical. Whether you agree with the conclusions in this second book or not, it will make you think.

\section{Gretchen Roedde MD}

Family physician

International reproductive health care consultant

Temiskaming Shores, Ont.

\section{REFERENCES}

1. Sarbib JL, Heller P. Fiscal space: response from World Bank and IMF. Lancet 2005;365:2085.

2. Ooms G, Schrecker T. Viewpoint: expenditure ceilings, multilateral financial institutions and the health of the poor. Lancet 2005;365:1821-3. 